\title{
Surface Modification of Mordenite in Nafion Composite Membrane for Direct Ethanol Fuel Cell and Its Characterizations: Effect of Types of Silane Coupling Agent \\ DOI:
}

10.1016/j.jece.2016.05.005

\section{Document Version}

Accepted author manuscript

Link to publication record in Manchester Research Explorer

\section{Citation for published version (APA):}

Prapainainar, C., Kanjanapasit, S., Kongkachuichay, P., Holmes, S., \& Prapainainar, P. (2016). Surface Modification of Mordenite in Nafion Composite Membrane for Direct Ethanol Fuel Cell and Its Characterizations: Effect of Types of Silane Coupling Agent. Journal of Environmental Chemical Engineering, 4(3), 2637-2646. https://doi.org/10.1016/j.jece.2016.05.005

Published in:

Journal of Environmental Chemical Engineering

\section{Citing this paper}

Please note that where the full-text provided on Manchester Research Explorer is the Author Accepted Manuscript or Proof version this may differ from the final Published version. If citing, it is advised that you check and use the publisher's definitive version.

\section{General rights}

Copyright and moral rights for the publications made accessible in the Research Explorer are retained by the authors and/or other copyright owners and it is a condition of accessing publications that users recognise and abide by the legal requirements associated with these rights.

\section{Takedown policy}

If you believe that this document breaches copyright please refer to the University of Manchester's Takedown Procedures [http://man.ac.uk/04Y6Bo] or contact uml.scholarlycommunications@manchester.ac.uk providing relevant details, so we can investigate your claim.

\section{OPEN ACCESS}




\section{Accepted Manuscript}

Title: Surface Modification of Mordenite in Nafion Composite Membrane for Direct Ethanol Fuel Cell and Its

Characterizations: Effect of Types of Silane Coupling Agent

Author: Chaiwat Prapainainar Sawanya Kanjanapaisit Paisan

Kongkachuichay Stuart M. Holmes Paweena Prapainainar

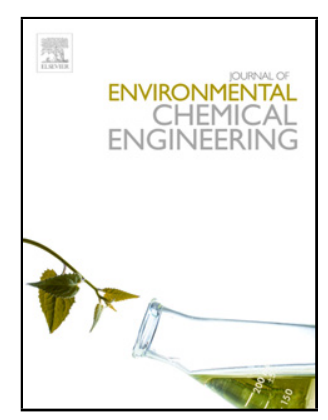

PII: S2213-3437(16)30174-9

DOI:

Reference: http://dx.doi.org/doi:10.1016/j.jece.2016.05.005

To appear in:

Received date: $\quad 28-1-2016$

Revised date: $\quad$ 2-5-2016

Accepted date: $\quad$ 4-5-2016

Please cite this article as: Chaiwat Prapainainar, Sawanya Kanjanapaisit, Paisan Kongkachuichay, Stuart M.Holmes, Paweena Prapainainar, Surface Modification of Mordenite in Nafion Composite Membrane for Direct Ethanol Fuel Cell and Its Characterizations: Effect of Types of Silane Coupling Agent, Journal of Environmental Chemical Engineering http://dx.doi.org/10.1016/j.jece.2016.05.005

This is a PDF file of an unedited manuscript that has been accepted for publication. As a service to our customers we are providing this early version of the manuscript. The manuscript will undergo copyediting, typesetting, and review of the resulting proof before it is published in its final form. Please note that during the production process errors may be discovered which could affect the content, and all legal disclaimers that apply to the journal pertain. 


\section{Surface Modification of Mordenite in Nafion Composite Membrane for Direct Ethanol}

Fuel Cell and Its Characterizations: Effect of Types of Silane Coupling Agent

Chaiwat Prapainainar ${ }^{\mathrm{a}, \mathrm{b}}$, Sawanya Kanjanapaisit ${ }^{\mathrm{c}}$, Paisan Kongkachuichay ${ }^{\mathrm{c}, \mathrm{d}}$, Stuart M.

$$
\text { Holmes }{ }^{\mathrm{e}} \text {, Paweena Prapainainar*c,d }
$$

aDepartment of Chemical Engineering, King Mongkut's University of Technology North Bangkok, Bangkok 10800, Thailand

${ }^{b}$ Research and Development Center for Chemical Engineering Unit Operation and Catalyst Design, King Mongkut's University of Technology North Bangkok, Bangkok 10800, Thailand

${ }^{\mathrm{c}}$ National Center of Excellence for Petroleum, Petrochemicals and Advance Material, Department of Chemical Engineering, Kasetsart University, Bangkok 10900, Thailand ${ }^{\mathrm{d}}$ Center for Advanced Studies in Nanotechnology, Applications in Chemical Food and Agricultural Industries, Kasetsart University, Bangkok 10900, Thailand

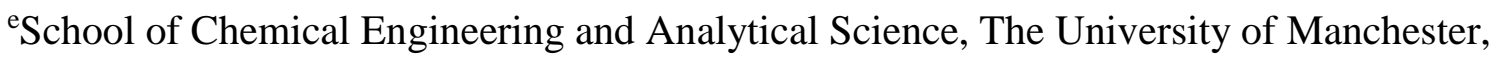
Manchester M13 9PL, UK

Email; chaiwat.r@eng.kmutnb.ac.th, pearry.sawanya@gmail.com, fengpsk@ku.ac.th, stuart.holmes@manchester.ac.uk, fengpwn@ku.ac.th

*Corresponding author at: Department of Chemical Engineering, Faculty of Engineering, Kasetsart University, Bangkok 10900, Thailand. Tel.: +66 27970999 Ext.1249; Fax: +66 25614621 . E-mail address: fengpwn@ku.ac.th (P. Prapainainar). 


\title{
Highlight
}

- Silane treated mordenite composite membrane was used for DEFC.

- Four types of silane coupling agents were treated on MOR surface.

- Sulfhydryl group in MPTES provided sulfonic group for enhance proton conductivity.

- MOR-MPTES/Nafion membrane had the highest selectivity at all temperature.

\begin{abstract}
Mordenite (MOR) has been used to solve the alcohol crossover in direct ethanol fuel cells. However, the lack of compatibility has been a problem. This paper shows the compatibility improvement of MOR in a Nafion composite membrane for use in a fuel cell using four types of silane coupling agents: gamma-glycidoxypropyltrimethoxysilane (GMPTS), (3-mercaptopropyl) trimethoxysilane (MPTS), (3-Mercaptopropyl) triethoxysilane (MPTES) and (3-Mercaptopropyl) methyl-dimethoxysilane (MPDMS). The coupling agents were used to treat the MOR surface before mixing with Nafion. Each type of silane was treated carefully and differently, depending on its structure. Their characterizations were also described. The results showed that better compatibility and a noticeable reduction in ethanol permeability were achieved when using all silane-treated MOR in the composite. It was found that the Nafion/MOR-MPTES membrane had the highest proton conductivity at all temperature ranges from $30-70^{\circ} \mathrm{C}$. This was due to the fact that the sulfhydryl $(-\mathrm{SH})$ functional group in MPTES provided the sulfonic group in its structure after the oxidation in the surface treatment process. These sulfonic groups at the MOR surface facilitated proton transport and improved the selectivity of the membrane.
\end{abstract}

Keywords: Mordenite/Nafion composite membrane; Silane surface treatment; Ethanol permeability; Compatibility; Direct ethanol fuel cell. 


\section{Introduction}

At present, the use of hydrogen and methanol as fuels in the fuel cell is common and has been commercially applied widely. Direct ethanol fuel cells have been under focus due to low emission levels produced and low cost of fuel. Compared with methanol, ethanol has a higher energy density and specific energy [1, 2]. Methanol is mainly obtained from petrochemical processes. Therefore, ethanol is considered a good choice for use in fuel cell development as it can be produced from renewable sources. The performance of a fuel cell depends mainly on the type of catalysts and the membrane used. A significant problem with membranes in a fuel cell is the crossover of alcohol through the membrane from the anode to the cathode. Nafion is a common polymer membrane used as a proton exchange membrane in fuel cells, due to its high proton conductivity and good mechanical properties. The structure of Nafion consists of two parts: a hydrophilic part which is a sulfonic acid group, and a hydrophobic part which is polytetrafluoroethylene (PTFE) [3]. It has been found that the selectivity, proton conductivity and methanol permeability ratio of Nafion are higher compared to other polymers such as chitosan and SPEEK membranes. However, the main problem of Nafion as a membrane in direct alcohol fuel cells is the permeation of alcohol from the anode side to the cathode side, which is known as crossover. The permeated alcohol can react with $\mathrm{O}_{2}$ and generate carbon dioxide at the cathode. As a result, the performance of the fuel cell is decreased [4]. In the report of Wang et al. [5], the selectivity values of chitosan and a Nafion ${ }^{\circledR} 117$ membrane were $1.49 \times 10^{4}$ and $1.71 \times 10^{4} \mathrm{Ss} / \mathrm{cm}^{3}$, respectively. In the report of Maab and Nunes [6], the permeability of ethanol for Nafion 117 was 5 times higher than a plain SPEEK membrane. However, it was found that the power density of a fuel cell using a Nafion $^{\circledR} 117$ membrane was higher than that of a SPEEK membrane. It has been a good choice for selection as a matrix polymer for polymer exchange membrane fuel cells (PEMFC), especially if the ethanol crossover is improved. 
Nafion polymer can be incorporated with filler, forming a composite membrane to improve its membrane properties [7-9]. Amiinu et al. [10] reported that doping Imidazole functionalized meoporous silica into Nafion showed an increase in proton conductivity to 1.06 $\mathrm{x} 10^{-2} \mathrm{Scm}^{-1}$ at $130{ }^{0} \mathrm{C}$. The presence of silica-imidazole within the matrix functioned as a transporting medium to facilitate proton conductivity. Kim et al. [11] enhanced the Nafion membrane by coating it with a delaminated AMH-3 (Microporous layered silicate)/Nafion nanocomposite layer, which resulted in a low methanol permeability and maintained a high proton conductivity. The methanol permeability of the nanocomposite layer was 1.6 times lower than Nafion 115 due to the smaller opening pore size of the filler particles in the nanocomposite layer than methanol molecules. Thus, they played a role as a barrier and blocked the methanol molecules by a tortuous pathway effect. These results were consistent with Kumar's work [12] that lower methanol permeability was achieved from Nafion coated and laminated with sulfonated polyvinyllidinefluoride (PVDF). Barbora et al. [13] studied neodymium oxide modified Nafion membrane for direct alcohol fuel cells. The pure Nafion and $5 \%$ wt composite membrane showed that the permeability of ethanol $\left(1.22 \times 10^{-7} \mathrm{~cm}^{2} / \mathrm{s}\right.$ and $0.85 \times 10^{-7} \mathrm{~cm}^{2} / \mathrm{s}$, respectively) was less than that of methanol $\left(1.38 \times 10^{-7} \mathrm{~cm}^{2} / \mathrm{s}\right.$ and $0.95 \times 10^{-7}$ $\mathrm{cm}^{2} / \mathrm{s}$, respectively) due to the larger molecule of ethanol. It was also found that the tensile strength of the composite membranes were higher than that of the pure recast Nafion membrane. Yen et al. [14] prepared sulfonated-silica/Nafion composite membranes, which have a higher selectivity than those of pristine Nafion. Adding silica-SH and silica- $\mathrm{SO}_{3} \mathrm{H}$ to the membrane decreased the methanol permeability by approximately $30 \%$ and $15 \%$, respectively. Another way to reduce alcohol crossover is by using a zeolite such as NaAzeolite incorporated with Nafion which has been reported to successfully reduce alcohol crossover $[15,16]$. The study found that the methanol permeability of the Nafion composite membrane, incorporated with zeolite-NaA which was treated by APTS silane was up to $55.96 \%$ lower than that of a Nafion ${ }^{\circledR} 117$ membrane. However, it was found that zeolite-NaA 
was not stable when used in a direct methanol fuel cell (DMFC) for long periods [17]. Various types of zeolite were incorporated with polymers, such as a zeolite beta-filled chitosan membrane. It was found that using zeolite beta can decrease the methanol permeability when compared with a pure chitosan membrane [5]. Yilser et al. [18] prepared the Nafion/zeolite composite membrane with different zeolite loading for a low humidity proton exchange membrane fuel cell (PEMFC). The results showed that water uptake and proton conductivity were enhanced due to the water retention properties of the zeolite and interaction between the Nafion and zeolite particles. PEMFC tests showed the $10 \mathrm{wt} . \%$ zeolite loading in the composite membrane was more stable and better than the Nafion membrane.

Cui et al. [19] synthesized Nafion-based membrane containing 5 wt.\% and 10 wt.\% of nano ammonium-X $\left(\mathrm{NH}_{4}-\mathrm{X}\right)$ and submicron $\mathrm{NH}_{4}-\mathrm{X}$ zeolite. The results showed that the water uptake, ion exchange capacity, and proton conductivity of the submicron 5 wt.\% $\mathrm{NH}_{4}-\mathrm{X}$ zeolite/Nafion composite membrane were higher than the Nafion membrane and the selectivity was more than twice of that of the Nafion membrane. The power density was 62.2 $\mathrm{mWcm}^{-2}$ at $60^{\circ} \mathrm{C}$, which was 3 times higher than that of the Nafion membrane. Moreover, the report of Kongkachuichay and Pimprom [20] showed that when incorporating analcime and faujasite as fillers with Nafion in PEMFC, the $\mathrm{H}_{2}$ permeation of both types of Nafion/zeolite composite membranes was lower than that of the Nafion ${ }^{\circledR} 117$ membrane. Nevertheless, mordenite (MOR) was suitable for use in a direct alcohol fuel cell [21]. MOR has 12membered and 8-membered rings, resulting in $6.7 \times 7.0$ and $2.9 \times 5.7$ Angstrom channels, respectively. The molecular size of water and ethanol is 2.6 Angstrom [22] and 5.2 Angstrom [23], respectively. Therefore, it can be seen that the ethanol molecule is smaller than the channels of the MOR. This can lead to better adsorption of water than ethanol. In summary, MOR as a type of zeolite has advantages of stability, high proton transport and higher water absorption than methanol or ethanol [24-26]. It can also be used in other applications [27]. It was found that there were some pinholes caused by poor compatibility between the Nafion 
polymer and the zeolite crystals which has been a problem reported in several studies [28-32]. Kwak et al. [33] synthesized MOR/Nafion composite membrane for high-temperature operation of PEMFC using various weight percentages of MOR. It was found that a higher MOR content led to lower tensile strength of the composite membranes (45 MPa for Nafion and $33 \mathrm{MPa}$ for 5\%wt MOR/Nafion). The strength was as low as $12 \mathrm{MPa}$ for $20 \% \mathrm{wt}$ MOR/Nafion membrane. This was due to poor compatibility between Nafion and MOR particles. The reduction in alcohol crossover and the higher compatibility can be achieved by improving the interfacial properties between the inorganic and organic parts in the composite membrane. In our previous work, Yoonoo et al. [21], 3-aminopropyl-triethoxysilane (APTS) and gamma-glycidoxypropyltrimethoxysilane (GMPTS) were used for MOR surface modification to increase the compatibility. It was found that GMPTS showed the best performance in DMFC, when 5 wt. \% of ground and coarse (non-ground) MOR in Nafion were used. The proton conductivity of Nafion/MOR-GMPTS was slightly lower, but its methanol permeability was much lower than that of the recast Nafion membrane. Nafion/MOR-GMPTS also showed better performance in DMFC. The power density of the Nafion/MOR-GMPTS membrane was 1.11 times that of the recast Nafion membrane. A silane coupling agent was also used to modify zeolite surface for membranes used in gas separation [29, 34]. Li et al. [29] reported that the permeability and selectivity of membranes made from silane modified zeolite were higher than those of membrane made from unmodified zeolite because the degree of partial pore blockage was decreased. Zhao et al. [35] reported the improvement of the adhesion strength of nanoparticles modified by grafting a silane coupling agent onto a $\mathrm{TiO}_{2}$ nanoparticles surface. Wang et al. [36] used $\gamma$ mercaptopropyltrimethoxysilane with sulfhydryl $(-\mathrm{SH})$ functional groups modified on the zeolite powders to improve the surface/channel of the zeolite substrates.

In this study, the focused was on reducing the permeation of ethanol and increasing the compatibility of the membrane that has been a crucial problem in DEFC. The main 
objective was the synthesis of Nafion/silanated-mordenite composite membranes to reduce ethanol permeability together with increasing the compatibility of the filler and the matrix for DEFC. MOR was used as inorganic filler and four types of silane were used as coupling agents to increase the compatibility. Further investigation of the effect of coupling agents in this study used gamma-glycidoxypropyltrimethoxysilane (GMPTS), (3-mercaptopropyl) trimethoxy silane (MPTS), (3-mercaptopropyl) triethoxysilane (MPTES) and (3Mercaptopropyl) methy-dimethoxysilane (MPDMS) to modify the surface of MOR before composite membrane fabrication. MPTS, MPTES, and MPDMS, which contain a sulhydryl group that can convert to a sulfonic group, have not yet been used to improve the MOR surface, were used in this study to compare with GMPTS, as had been used in our previous studies [21]. These mercapto silanes should benefit from an increase in the sulfuric group ($\mathrm{SO}_{3}$ ). Therefore, these silanes were applied in this study. $5 \mathrm{wt} . \%$ MOR was incorporated with Nafion composite membrane synthesis for use in the direct ethanol fuel cell (DEFC). The chemical and physical properties of the composite membranes were characterized and their ethanol permeability and proton conductivity were systematically investigated.

\section{Methodology}

\subsection{Materials}

Nafion solution was purchased from Ion Power. MOR-Na with a Si/Al molar ratio of 13 was purchased from Zeolyst International. Gamma-glycidoxypropyltrimethoxysilane (GMPTS), (3-Mercaptopropyl) trimethoxysilane (MPTS), (3-Mercaptopropyl) triethoxysilane (MPTES) and (3-Mercapto propyl) methy-dimethoxysilane (MPDMS) were purchased from Sigma-Aldrich. Sulfuric acid, hydrogen peroxide, ethanol, methanol, N,Ndimethylformamide, dichloromethane, ammoniumcholride, toluene and aluminumtrichloride were used. De-ionized water was used throughout the study.

\subsection{Preparation of mordenite}


Mordenite-Na was ground in a ball mill and was then protonated to obtain MOR-H in $1 \mathrm{M}$ sulfuric acid for $24 \mathrm{~h}$, dried in an oven before being calcined at $550{ }^{\circ} \mathrm{C}[21,37]$. Functionalization of MOR-H by GMPTS silane was carried out according to the procedure described in the literature [21]. Briefly, $4 \mathrm{~g}$ MOR-H was added to the mixture of $4 \mathrm{ml}$ GMPTS and $120 \mathrm{ml}$ dichloromethane. The mixture was stirred for $24 \mathrm{~h}$, centrifuged, rinsed in dichloromethane and re-dispersed in an ultrasonic bath. Finally it was dried at $100{ }^{\circ} \mathrm{C}$ for $24 \mathrm{~h}$ to obtain MOR-GMPTS. For MPTS, $4 \mathrm{~g}$ MOR-H was mixed in the solution of $8 \mathrm{ml}$ MPTS in $80 \mathrm{ml}$ toluene and the reaction was carried out at the reflux temperature of toluene at $110{ }^{\circ} \mathrm{C}$ for $24 \mathrm{~h}$. After washing with ethanol and de-ionized water to remove the silane residues, it was oxidized in a $30 \mathrm{wt} \% \%$ hydrogen peroxide solution at room temperature for $24 \mathrm{~h}$ to convert the $-\mathrm{SH}$ groups into $-\mathrm{SO}_{3} \mathrm{H}$ groups and form MOR-MPTS [38]. The reactions of MPTES and MPDMS used the same method as that of MPTS but included adding a catalyst into the mixture. The catalyst solutions were prepared by dissolving $1 \mathrm{~g} \mathrm{AlCl}_{3}$ in the mixture of $20 \mathrm{ml}$ ethanol and $20 \mathrm{ml}$ toluene. They were mixed under stirring at $70{ }^{\circ} \mathrm{C}$ for $1 \mathrm{~h}$. After that, $4 \mathrm{ml}$ MPTES and $40 \mathrm{ml}$ toluene were mixed under stirring at room temperature for 30 min. Subsequently, $5 \mathrm{ml}$ catalyst solution, $44 \mathrm{ml}$ silane solution and $2 \mathrm{~g}$ MOR-H were mixed and refluxed under stirring at $110{ }^{\circ} \mathrm{C}$ for $24 \mathrm{~h}$. MOR was washed with ethanol and de-ionized water and further oxidized in $30 \mathrm{wt} . \%$ hydrogen peroxide solution under ambient conditions and then separated using a centrifuge. The final drying stage occurred at $100{ }^{\circ} \mathrm{C}$ for $24 \mathrm{~h}$ to obtain MOR-MPTES. For the MPDMS treatment, the same procedure was used as for MPTES except that MPDMS was used instead of MPTES and denoted as MOR-MPDMS.

\subsection{Preparation of Nafion/MOR composite membrane and pretreatment}

Nafion/MOR composite membranes were cast following the standard solution casting method as reported in Yoonoo et al. [21]. First, $7.5 \mathrm{ml}$ of $20 \mathrm{wt} \%$ Nafion solution was mixed with $34 \mathrm{ml}$ of alcohol (15:85 volume ratio of ethanol/methanol) and $20.5 \mathrm{ml}$ of $\mathrm{N}, \mathrm{N}$ dimethylformamide (DMF). Then $0.078 \mathrm{~g}$ of treated MOR was added into the mixture and 
suspended using an ultrasonic bath and magnetic stirrer for $2 \mathrm{~h}$ to ensure good suspension of the MOR powder in the Nafion solution. After that, the suspension was poured onto a Petri dish and dried in a vacuum oven at $80{ }^{\circ} \mathrm{C}$ for $20 \mathrm{~h}$, followed by further heat treatment at $150{ }^{\circ} \mathrm{C}$ for $4 \mathrm{~h}$. The cast membrane was then cooled down to room temperature and was then treated by soaking in boiling de-ionized water for $10 \mathrm{~min}$, ensuring full hydration. Membranes were then boiled in $5 \mathrm{vol} . \%$ hydrogen peroxide in water at $80{ }^{\circ} \mathrm{C}$ for $30 \mathrm{~min}$ to remove the organic residues, followed by rinsing twice with deionized water and boiling in $1 \mathrm{M}$ sulfuric acid for $30 \mathrm{~min}$. Next, they were rinsed and boiled in de-ionized water 3 times each for $10 \mathrm{~min}$. Finally the membranes were stored in de-ionized water before use.

\subsection{Characterizations}

The crystalline structures of MOR before and after grinding and after each silane treatment were examined using X-ray diffractrometry (XRD) on a BRUKER D8 Advance A25 equipped with $\mathrm{Cu}-\mathrm{K} \alpha \mathrm{X}$-ray radiation $(\lambda=1.5418 \AA)$ to confirm their structures. The result of the MOR surface treatment by silane were observed using Fourier transform infrared spectrophotometry (FTIR, Perkin Elmer System 2000) in the range 4000-400 $\mathrm{cm}^{-1}$. The quantity of silane grafted on the MOR surface was determined by thermo gravimetric analysis (TGA) with air flowing at a heating rate of $5{ }^{\circ} \mathrm{C} / \mathrm{min}$ from $25^{\circ} \mathrm{C}$ to $1,100{ }^{\circ} \mathrm{C}$.

The morphologies of the membranes were observed with scanning electron microscopy (SEM, Philips: XL30 \& EDAX). The dispersion of MOR in the Nafion matrix was investigated by applying the elemental mapping using the EDS mode equipped with SEM undertaking at the cross section of the membranes.

\subsection{Water uptake and ethanol solution uptake}

Water and ethanol uptake is an approach which can be used to study the behavior of the composite membrane when it comes into contact with water and ethanol. The water uptake of membranes was determined by measuring the weight different between the dry and fully hydrated membranes. The membranes were soaked in de-ionized water for $24 \mathrm{~h}$ at room 
temperature, the excess water adsorbed by filter paper and subsequently the membranes were weighed to obtain $W_{\text {wet }}$, were then dried under vacuum at $80{ }^{\circ} \mathrm{C}$ for $2 \mathrm{~h}$ and re-weighed to obtain $W_{d r y}$. To test for ethanol solution uptake, they were immersed in a $12 \mathrm{M}$ ethanol solution and tested in the same procedure as for water uptake. The uptake was calculated from Eq.(1) [39]:

$$
\operatorname{uptake}(\%)=\left(\frac{W_{w e t}-W_{d r y}}{W_{d r y}}\right) \times 100 \%
$$

\subsection{Ion Exchange Capacity (IEC)}

Ion-exchange capacity (IEC) of the membranes can be used as an approximation of the proton conductivity [40], indicating quantity of acid equivalents per gram of polymer membrane [20, 41]. The IEC values of the composite membranes were determined with the titration method. The composite membranes in $\mathrm{H}^{+}$were converted to $\mathrm{Na}^{+}$by immersing in a $0.1 \mathrm{M} \mathrm{NaCl}$ solution for $24 \mathrm{~h}$. After that, the remaining solution was titrated with $0.02 \mathrm{M}$ $\mathrm{NaOH}$ using phenolphthalein as an indicator. The IEC was calculated from Eq.(2) [42].

$I E C=\frac{V_{e q} \times C_{N a O H}}{m_{d}}$

where $V_{e q}$ is the volume of $\mathrm{NaOH}$ solution $(\mathrm{ml}), C_{\mathrm{NaOH}}$ is the concentration of $\mathrm{NaOH}$ solution (mol/l) and $m_{d}$ is the weight of the dry membrane $(\mathrm{g})$.

\subsection{Proton conductivity}

AC impedance spectroscopy (Autolab) was used to measure the membrane resistance using the two-probe method over a frequency range of 10,000-100 $\mathrm{Hz}$ with an oscillating voltage of $10 \mathrm{mV}$. The proton conductivity $(\sigma, \mathrm{S} / \mathrm{cm})$ of membranes was then calculated using Eq. (3) [20]. Prior to the measurement, the membranes were immersed in $1 \mathrm{M}$ sulfuric acid for $24 \mathrm{~h}$. During the measurement, membrane samples were placed between two platinum electrodes and resistance was measured at three points in each membrane.

$\sigma=\frac{d}{R_{m} A}$ 
where $d$ is the thickness of the membrane $(\mathrm{cm}), A$ is the sample area of the membrane $\left(\mathrm{cm}^{2}\right)$ and $R_{m}$ is the membrane resistance $(\Omega)$.

\subsection{Ethanol permeability}

The ethanol permeability of the membranes was determined using the two compartments diffusion cell technique, as described in the literature [21]. The cell consists of two compartments: feed and permeate, separated by the membrane sample. The feed and permeate compartments were filled with a solution of ethanol and de-ionized water, respectively. The ethanol concentration difference between the feed and permeate caused ethanol permeation across the membrane. The ethanol concentration in the feed was assumed to remain unchanged during the experiment. Finally, the ethanol concentration on the permeate side was measured as a function of time and determined by using gas chromatography (GC 8A SHIMADZU) with a Porapak-Q column. The ethanol permeability $\left(P, \mathrm{~cm}^{2} / \mathrm{s}\right)$ was calculated using Eq.(4) [43].

$P=\frac{k V L}{S C_{A 0}}$

where $k$ is the slope of the plot of the concentration in the permeate compartment versus time $\left(\mathrm{mol} / \mathrm{cm}^{3} \mathrm{~s}\right), V$ is the volume of the permeate compartment $\left(\mathrm{cm}^{3}\right), S$ and $L$ are the membrane area $\left(\mathrm{cm}^{2}\right)$ and thickness $(\mathrm{cm}) . C_{A O}$ is the initial concentration of ethanol in a feed compartment $\left(\mathrm{mol} / \mathrm{cm}^{3}\right)$. Each sample was measured three times. The ethanol concentration was varied at 1,2 and $4 \mathrm{M}$ and the temperature was varied at $30^{\circ} \mathrm{C}, 50^{\circ} \mathrm{C}$ and $70{ }^{\circ} \mathrm{C}$.

\section{Results and discussion}

\subsection{Characterization of MOR before and after modification}

MOR powder purchased from Zeolyst was ground resulting in an average particle size of $3.5 \mu \mathrm{m}$. To ensure that the crystallinity of MOR was not changed due to grinding, protonating and the silane treatment, the particles were examined using XRD. The XRD 
fingerprints of each treatment and each type of MOR are shown in Fig.1. It can be seen that the surface-modified MOR shows identical characteristic peaks to the pristine MOR. This meant the crystalline structures of the modified MOR were unchanged when compared with the pristine MOR.

Compatibility between the polymer and the surface of the inorganic filler is a key issue in determining the final membrane properties and performance. Therefore, good adhesion between the inorganic filler and matrix is crucial in composite applications. The adhesion can be improved by surface modification. TGA was used to confirm the success of the surface modification of MOR using silanes. Consequently, FT-IR was used to find the functional group of silane attached on the surface of MOR. The functional group of silane and their structures are shown in Fig. 2.

The FT-IR results in Fig.3 show the FT-IR spectra of MOR-H, MOR-GMPTS, MORMPTS, MOR-MPTES and MOR-MPDMS samples. Regarding MOR-GMPTS, it was found that the spectrum at $912 \mathrm{~cm}^{-1}$ was assigned to the epoxy characteristic band [44]. It was stated in the literature that after heating, hydrolysis-condensation and oxidation treatments, the epoxy peak was no longer present in the spectrum $[45,46]$. At $1086 \mathrm{~cm}^{-1}$, it was assigned to the Si-O-C chains in the silane [47]. Moreover, there was a band at 2940-2960 $\mathrm{cm}^{-1}$ assigned to the $\mathrm{CH}_{2}$ group. The important evidence to confirm the success of the silane treatment was revealed by the decrease in $-\mathrm{OH}$ groups at 1630 and $3430 \mathrm{~cm}^{-1}$, as can be clearly seen in Fig. 3(a) [48].

Considering the spectra of MOR-MPTS compared with MOR-H in Fig. 3(b), the intensity of the bands at 1630 and $3430 \mathrm{~cm}^{-1}$ decreased after silane modification. This was due to the $\mathrm{OH}$ group of MOR reacting with the alkoxy group of silane. Therefore, the number of $\mathrm{OH}$ groups decreased. At $2565 \mathrm{~cm}^{-1}$, the spectra were assigned to the sulfhydryl (SH) characteristic bands in the MPTS spectra. However, the sulfhydryl peak was no longer present 
in the spectrum, which indicated that the sulfhydryl group of MPTS was converted to a sulfonic acid group $\left(\mathrm{HSO}_{3}{ }^{-}\right)$. Similar behavior for FT-IR of the MPTS-treated zeolite data was reported elsewhere [44]. Nevertheless, the peak of the sulfonic acid group that appeared at $1,000-1,200 \mathrm{~cm}^{-1}$ did not appear in the MOR-MPTS spectra because they were overlapped by the peak of $\mathrm{TO}_{4}(\mathrm{Si}, \mathrm{Al}$ tetrahedral units) $[5,38]$. This was also the case for the spectra of MPTES and MPDMS. However, the peaks of MOR-GMPTS, MOR-MPTS, MOR-MPTES and MOR-MPDMS at around 3430 and $1630 \mathrm{~cm}^{-1}$ (which were assigned to the stretching of $\mathrm{OH}$ and bending vibrations of $\mathrm{H}-\mathrm{O}-\mathrm{H}$ bonds on the surface of MOR, respectively) were found clearly with decreased intensities [48]. The FT-IR results definitely confirmed the success of the silane treatment. However, to determine the amount of silane treated on the MOR surface, TGA was used to obtain further details.

The TGA curves are shown in Fig. 4. From the results, the weight loss of samples can be divided into two intervals separated at $400{ }^{\circ} \mathrm{C}$. At $25-400^{\circ} \mathrm{C}$, for all types of MOR, the reduction of weight was from water evaporation of only the weakly adsorbed water [15, 48]. Above $400{ }^{\circ} \mathrm{C}$, for unmodified MOR, a $0.67 \%$ loss was assigned to the strongly bound water and dehydroxylation of the external zeolite surface, according to Eq. (5) [15]. The weight loss of MOR was negligible.

$2 \mathrm{SiOH} \rightarrow \mathrm{Si}-\mathrm{O}-\mathrm{Si}+\mathrm{H}_{2} \mathrm{O}$

In the case of modified-MOR, between 400 and $1,100{ }^{\circ} \mathrm{C}$, around $4.5-10 \%$ weight losses were found. Compared with unmodified MOR, these differences could be explained by the surface modification on the MOR surface. As the strongly adsorbed water molecules were bound to the sodium cation within the zeolite windows, the internal pore structure was not affected by the silane. Therefore, the amount of water loss at higher temperatures remained approximately the same for all samples. The weight loss between 400 and $1,100{ }^{\circ} \mathrm{C}$ for modified-MOR should be attributed to the decomposition of organic substances which were silanes that had been grafted on the surface of MOR [15]. This indicated that the silanes 
successfully bonded at the surface of MOR. The amount of grafted silane on the MOR surface was calculated. It was around 3.5\%, 4\%, 6\%, and $8.9 \%$ for surfaces treated with MPDMS, MPTS, GMPTS, and MPTES, respectively. This result supported the FT-IR results that silane was successfully grafted onto the MOR surface.

\subsection{Characterization of the Nafion composite membranes}

Fig.5 shows SEM images (first image on the left) and EDXS mapping images $\left(2^{\text {nd }}\right.$ image on the left: Si-element mapping, $3^{\text {rd }}$ image on the left: Al-element mapping, $4^{\text {th }}$ image on the left: S-element mapping, and the right image: F-element mapping)of the recast Nafion, Nafion/MOR-H， Nafion/MOR-GMPTS， Nafion/MOR-MPTS， Nafion/MOR-MPTES and Nafion/MOR-MPDMS composite membranes. The red color in EDX images represents Si and $\mathrm{Al}$ in the MOR structure, while black and green colors represent $\mathrm{S}$ and $\mathrm{F}$ in the Nafion structure, respectively. All membranes had a thickness of 125-130 $\mu \mathrm{m}$. Fig. 5(a) shows the cross section of a recast Nafion membrane, which has a homogenous layer. The dispersion of an MOR-H particle which had not been functionalized by silanes is shown in Fig. 5(b). It was found that there were some pin holes (as depicted using arrows) leading to low compatibility between Nafion and MOR particles. The cross sectional layer for all types of membranes that contained silane-treated MOR consisted of two layers with a Nafion-rich layer on top and an MOR-rich layer on the bottom, as shown in Fig. 5 (c-f). Moreover, it was found that some small particles of MOR were dispersed in the Nafion layer, which could be observed using the $\mathrm{Al}$ and Si mapping from EDS. The separation of MOR particles might be due to the fact that the sizes of the particles were rather large. This was a limitation of the grinding $[5,14,15,38$, 49]. Grinding in a fluid energy mill which is commonly used in the pharmaceutical and cosmetic industries may provide very fine-size products. It can be clearly observed that the smaller particles were able to disperse in the Nafion matrix layers. Therefore, more homogeneous dispersion may be improved by using a reduced size of MOR particles. 
The tensile strength of the MPTES-MOR/Nafion and recast Nafion were determined using universal tensile testing. The data are provided in the supplementary data. Tensile strength of recast Nafion was $17.68 \pm 0.61 \mathrm{MPa}$ while that of MPTES-MOR/Nafion was $14.40 \pm 0.46 \mathrm{MPa}$. It was found that the strength of the composite was slightly lower than that of recast Nafion. This might be due to two layers of MOR and Nafion that were formed. This was consistent to those found by Kwak et al. was less than that of pure Nafion, revealing poor compatibility of the composite due to no surface treatment of MOR was performed [33]. The size of particle filler was found to have an effect on the strength of polymer composite. It was reported that polymer composite with smaller particle size exhibit slightly higher tensile strength than that with larger particle size [50-52]. Therefore, reducing the size of MOR was an essential step in membrane composite fabrication.

\subsection{Water and ethanol uptake}

Water and ethanol uptake of membranes was carried out in order to study the effect of adsorption on the membrane properties. Since water is a major factor that causes the mechanical motion of proton transport within the membrane, it influences performance inside the fuel cell. Fig. 6 shows the water and ethanol uptake of all composite membranes. It was found that the water uptake of most composite membranes was lower than that of recast Nafion. This may be due to two reasons: that MOR was more hydrophobic than Nafion and 
that the addition of zeolite resulted in a decrease in the ability to adsorb water molecules [5, 14]. The water uptake for all types of membranes was much higher than their ethanol uptake. This indicated that composite membranes adsorb water molecules in preference to ethanol molecules [38]. This property was an advantage for membrane use in DEFC as $\mathrm{H}_{3} \mathrm{O}^{+}$transfers more easily than ethanol.

\subsection{Ion-exchange capacity}

Ion exchange capacity (IEC) is an indirect and reliable approximation of proton conductivity. It represents the number of moles of sulfuric acid per $1 \mathrm{~g}$ of dry membrane. Hydrogen $\left(\mathrm{H}^{+}\right)$ions in the membranes were exchanged with sodium ions from the $\mathrm{NaCl}$ solution. The IEC values of all membranes are shown in Fig. 7. It can be clearly seen that commercial Nafion and recast Nafion had the highest IEC values. In contrast, Nafion/MOR-H displayed the lowest IEC values. These results corresponded with reports from Wang et al. [5] and Lin et al. [45]. Moreover, in our previous study [21], all mercapto silanes with a sulhydryl group (-SH) were not used. GMPTS-treated MOR was found as better than MOR-H. A later study discovered that using mercapto-silanes could be of benefit by having a sulfuric acid group in the composite membrane. When compared with silane modified-MOR membranes, it was found that Nafion/MOR-MPTS and Nafion/MOR-MPTES had higher IEC values than Nafion/MOR-GMPTS, because MPTS and MPTES contained the $-\mathrm{HSO}_{3}$ group which was converted from the $-\mathrm{SH}$ group after oxidization with hydrogen peroxide. Therefore, the hydrogen ion in the $-\mathrm{HSO}_{3}$ group contained in the composite membrane can also exchange with the $\mathrm{Na}$ ion, leading to increased IEC value [5, 45].

\subsection{Proton conductivity}

The proton conductivity results of all membranes at various temperatures of 30,50 and $70{ }^{\circ} \mathrm{C}$ are shown in Fig.8. In general, proton transport in Nafion can occur via two 
mechanisms. The first mechanism is by a Grotthus or jump mechanism[38]. The protons pass down from the $-\mathrm{OH}$ groups or the $\mathrm{SO}_{4}{ }^{2-}$ ion groups to each other by jumping. The proton produced by oxidation of ethanol on the anode side adheres to water molecules, resulting in a provisional hydronium ion being formed, and a different proton from the same hydronium ion hops onto the other water molecules. The second mechanism is called a vehicle mechanism [5]. The proton transfers in the form of a complex species, like $\mathrm{H}_{3} \mathrm{O}^{+}$, by combining with the solvent molecules such as water. Therefore, the vehicle mechanism is highly dependent on the amount of water or ethanol molecules in the membrane [53, 54]. It was found from the experiment that Nafion/MOR-MPTES composite membranes had the highest proton conductivity for all conditions which were $0.078 \pm 0.011,0.082 \pm 0.004$ and $0.089 \pm 0.004$ S/cm at 30,50 and $70{ }^{\circ} \mathrm{C}$, respectively. This may be due to the $-\mathrm{HSO}_{3}$ group in MPTES being a good proton-passing medium [14]. Furthermore, MPTES had an ethoxy group which reacted more easily with MOR than the methoxy group in other silanes. Moreover, catalyst use in MPTES helped to facilitate the reaction of silane and MOR[38, 45]. When considering the effect of temperature, it was found that increasing the temperature resulted in higher proton conductivity and higher ethanol crossover. This was related to the Arrhenius effect, as shown in Eq. (6)[45].

$\sigma=\sigma_{0} \exp -\frac{E_{a}}{R T}$

where $\sigma$ is the proton conductivity $(\mathrm{S} / \mathrm{cm}), \sigma_{0}$ is a pre-exponential factor, $R$ is the gas constant $(8.314 \mathrm{~kJ} / \mathrm{molK}), T$ is the absolute temperature $(\mathrm{K})$, and $E_{a}$ is the activation energy $(\mathrm{kJ} / \mathrm{mol})$. It can be seen that the proton conductivity is proportional to the temperature. When temperature of the system is raised, the proton conductivity increases. Moreover, in the fuel cell stack where the catalyst and water are present, the dissociation reaction of ethanol to free protons $\left(\mathrm{H}^{+}\right)$has a higher rate constant $(k)$ at a higher temperature. Eq. (7) shows the dissociation reaction of ethanol on the anode side in a fuel cell [55] and Eq. (8) shows the 
relationship of the rate constant $(\mathrm{k})$ with temperature [56]. This result was consistent with the report of Lin et al.[45].

$\mathrm{CH}_{3} \mathrm{CH}_{2} \mathrm{OH}+3 \mathrm{H}_{2} \mathrm{O} \rightarrow 2 \mathrm{CO}_{2}+12 \mathrm{H}^{+}+12 \mathrm{e}^{-}$

$k=k_{0} \exp -\frac{E}{R T}$

where $k$ is the rate constant, $k_{0}$ is the frequency or pre-exponential factor, $R$ is the gas constant $(8.314 \mathrm{~J} / \mathrm{molK}), T$ is the absolute temperature $(\mathrm{K})$ and $E$ is the activation energy $(\mathrm{kJ} / \mathrm{mol})$.

\subsection{Ethanol permeability}

Ethanol permeability testing in a diffusion cell was carried out systematically to evaluate the performance of the composite membranes. The low permeability of ethanol indicated that the membrane has a good ability to inhibit the permeation of ethanol. The high ethanol permeability resulted in the poor performance of the fuel cell. The ethanol permeability of all membranes is shown in Fig. 9 - 11. It can be observed that Nafion membranes had a high ethanol permeability compared with the other composite membranes and Nafion/MOR-MPTES had the lowest permeability. At $1 \mathrm{M}$ ethanol concentration, the ethanol permeability of recast Nafion was higher than Nafion/MOR-MPTES by $24.16 \%$ at $30{ }^{\circ} \mathrm{C}, 24.98 \%$ at $50{ }^{\circ} \mathrm{C}$ and $34.79 \%$ at $70{ }^{\circ} \mathrm{C}$. At $2 \mathrm{M}$ ethanol concentration, the ethanol permeability of recast Nafion was higher than Nafion/MOR-MPTES by $24.86 \%$ at $50{ }^{\circ} \mathrm{C}$ and $17.41 \%$ at $70{ }^{\circ} \mathrm{C}$. These values of ethanol permeability were comparable to the study of Barbora et al. [13] which $\mathrm{Nd}_{2} \mathrm{O}_{3}$ was used with the Nafion membrane for DEFC. Furthermore, at $4 \mathrm{M}$ ethanol concentration, the ethanol permeability of recast Nafion was higher than Nafion/MOR-MPTES by $59.82 \%$ at $50{ }^{\circ} \mathrm{C}$ and $31.95 \%$ at $70{ }^{\circ} \mathrm{C}$. These results indicated that the MOR-MPTES incorporated into Nafion was able to reduce the ethanol-crossover from the feed side to the permeate side in the diffusion cell, because the dispersion of zeolite particles 
increased the distance and the tortuosity for ethanol molecules to transfer across the membrane in the cell. Moreover, the incorporation of MOR in the polymer compressed the volume between the polymer chains. It also reduced the swelling and reduced the adsorption of ethanol in the membranes [38], leading to the decrease in permeability.

The effect of MOR surface modification on the suppression of the ethanol crossover property was studied by varying the types of silane. It was clearly found that the silane chain grafted on MOR particles enhanced the compatibility between MOR and Nafion in all composite membranes. Considering the types of organic groups in silanes, silane containing sulfonic acid (- $\left.\mathrm{HSO}_{3}\right)$ in MPTS was compared with silane containing the epoxy group (-C-C-) in GMPTS. It was found that the Nafion/MOR-MPTS membrane had lower ethanol permeability when compared with the Nafion/MOR-GMPTS membrane. This was due to the sulhydryl group (-SH) in MPTS being converted to a sulfonic acid group while GMPTS had no $-\mathrm{HSO}_{3}$ group. This group on the treated MOR surface was the same as the $-\mathrm{HSO}_{3}$ group in the Nafion solution. Therefore, the reaction of treated MOR with Nafion occurred easily. Moreover, the $-\mathrm{HSO}_{3}$ group helped to facilitate the proton conducting ability. This was in agreement with the report of Lin et al. [45]. Considering the number of alkoxy groups of silanes, the MPDMS structure with two chains of the methoxy group was compared with MPTS with three chains of the methoxy group to react with MOR. It was found that the Nafion/MOR-MPDMS membrane had higher ethanol permeability when compared with the Nafion/MOR-MPTS membrane. This may be because MPDMS had weaker interaction with the zeolite than did MPTS, as MPDMS has two chains while MPTS has three chains to react with the zeolite surface. Considering the types of alkoxy group in all mercapto silanes that were used, MPTES had an ethoxy group while MPTS had a methoxy group to react with the OH group on the surface of MOR. It was found that the Nafion/MOR-MPTES membrane had lower ethanol permeability when compared with the Nafion/MOR-MPTS membrane. This may be due to the need to use a catalyst in the reaction of silane containing the ethoxy group 
[57]. Therefore, in the MPTES treatment, the $\mathrm{AlCl}_{3}$ catalyst was used, which meant that MPTES was easier to hydrolyze than MPTS, which contains a methoxy group. This resulted in superior performance in the case of MPTES compared with MPTS.

The temperature of the ethanol feed solution was an important factor that affected the ethanol permeability. It resulted in an increase of the ethanol diffusion rate and proton conductivity, due to the decreased resistance of the membranes. For all ethanol concentrations and for all the membranes, an increase in the temperature increased the permeability. These results agreed with the reports of Mukoma et al. [43] and Yoonoo et al. [21]. The increased temperature caused the mechanical strength of the membranes to decrease, which led to the degradation of the membranes.

\section{Conclusions}

MOR/Nafion composite membranes were synthesized to reduce the ethanol crossover in DEFC. Four types of silanes, having different functional groups of epoxy (GMPTS) and sulhydryl (MPTS, MPTES, and MPDMS), were selected to treat on the MOR surface to improve the compatibility of MOR in the composite membrane for DEFC. They successfully modified the surface of MOR, as confirmed by the FT-IR and TGA results. These silanes improved the compatibility between the organic and the inorganic parts as well as the interfacial properties, leading to the obvious reduction of the ethanol permeability of the membranes. This was indicated by much lower ethanol permeability and higher selectivity of those composite membranes compared to the recast Nafion membrane. The Nafion/MORMPTES composite membranes showed excellent proton conductivity relative to all other membranes under all conditions and had the lowest ethanol permeability under almost all conditions. This was due to several reasons; (1) the sulhydryl group (-SH) in MPTES was converted to a sulfonic acid group $\left(-\mathrm{SO}_{3}\right)$ to facilitate the proton transfer while there was none in GMPTS, (2)three chains of the ethoxy group in MPTES form strong bond, while there are 
two chains in the MPDMS structure leading to weak interaction with the MOR surface (3) ethoxy group in MPTES and was easier to hydrolyze than the methoxy group in MPTS. This resulted in the Nafion/MOR-MPTES composite membranes having the highest selectivity of about $5.42 \times 10^{4} \mathrm{Ss} / \mathrm{cm}^{3}$ at $30{ }^{\circ} \mathrm{C}$ in a $1 \mathrm{M}$ ethanol concentration. In conclusion, this paper provides the method and explanation for developing a suitable composite membrane for direct ethanol fuel cells. It also shows the results and explanation of the effect of a functional group of silanes on the ethanol permeability and compatibility in the composite membranes for DEFC.

\section{Acknowledgements}

The authors would like to acknowledge the Thailand Research Fund (TRF) for funding the project TRG5780256. Our thanks are also to the Kasetsart University Research and Development Institute (KURDI). The authors gratefully acknowledge the financial support from the Faculty of Engineering, Kasetsart University Research Development Institute (KURDI), and the Center for Advanced Studied in Nanotechnology for Chemical, Food and Agricultural Industries, Kasetsart University. Thanks are also due to the National Center of Excellence for Petroleum, Petrochemicals, and Advanced Materials.

\section{References}

[1] Mann J, Daubin S, Bocarsly AB. Catalysts for direct ethanol fuel cells. 2004;Prepr. Pap.Am. Chem. Soc., Div. Fuel Chem., 49(2), 663.

[2] Giddey S, Badwal SPS, Kulkarni A, Munnings C. A comprehensive review of direct carbon fuel cell technology. Progress in Energy and Combustion Science. 2012;38(3):360-99. [3] Schmidt-Rohr K, Qiang C. Parallel cylindrical water nanochannels in Nafion fuel-cell membranes. Nature Materials. 2008;7:75-83.

[4] Paganin VA, E. Sitta, T. Iwasita, Vielstich aW. Methanol crossover effect on the cathode potential of a direct PEM fuel cell. Journal of Applied Electrochemistry. 2005;35(12):123943.

[5] Wang Y, Yang D, Zheng X, Jiang Z, Li J. Zeolite beta-filled chitosan membrane with low methanol permeability for direct methanol fuel cell. Journal of Power Sources.

2008;183(2):454-63.

[6] Maab H, Nunes SP. Modified SPEEK membranes for direct ethanol fuel cell. Journal of Power Sources. 2010;195(13):4036-42. 
[7] Aragaw BA, Su W-N, Rick J, Hwang B-J. Highly efficient synthesis of reduced graphene oxide-Nafion nanocomposites with strong coupling for enhanced proton and electron conduction. RSC Advances. 2013;3(45):23212-21.

[8] Kumar R, Xu C, Scott K. Graphite oxide/Nafion composite membranes for polymer electrolyte fuel cells. RSC Advances. 2012;2(23):8777-82.

[9] Wang Y, Han G, Tian Z, Wang M, Li J, Wang X. Nafion[registered sign]/SiO2/m-BOT composite membranes for improved direct methanol fuel cell performance. RSC Advances. 2014;4(88):47129-35.

[10] Amiinu IS, Li W, Wang G, Tu Z, Tang H, Pan M, et al. Toward Anhydrous Proton Conductivity Based on Imidazole Functionalized Mesoporous Silica/Nafion Composite Membranes. Electrochimica Acta. 2015;160:185-94.

[11] Kim J, Jeon J-D, Kwak S-Y. Delamination of microporous layered silicate by acidhydrothermal treatment and its use for reduction of methanol crossover in DMFC.

Microporous and Mesoporous Materials. 2013;168:148-54.

[12] Kumar P, Kundu PP. Coating and lamination of Nafion117 with partially sulfonated PVdF for low methanol crossover in DMFC applications. Electrochimica Acta.

2015;173:124-30.

[13] Barbora L, Singh R, Shroti N, Verma A. Synthesis and characterization of neodymium oxide modified nafion membrane for direct alcohol fuel cells. Materials Chemistry and Physics. 2010;122(1):211-6.

[14] Yen C-Y, Lee C-H, Lin Y-F, Lin H-L, Hsiao Y-H, Liao S-H, et al. Sol-gel derived sulfonated-silica/Nafion ${ }^{\circledR}$ composite membrane for direct methanol fuel cell. Journal of Power Sources. 2007;173(1):36-44.

[15] Li X, Roberts EPL, Holmes SM, Zholobenko V. Functionalized zeolite A-nafion composite membranes for direct methanol fuel cells. Solid State Ionics. 2007;178(1920):1248-55.

[16] Jafari M, Nouri A, Mousavi SF, Mohammadi T, Kazemimoghadam M. Optimization of synthesis conditions for preparation of ceramic (A-type zeolite) membranes in dehydration of ethylene glycol. Ceramics International. 2013;39(6):6971-9.

[17] Scott K, Taama WM, Argyropoulos P. Performance of the direct methanol fuel cell with radiation-grafted polymer membranes. Journal of Membrane Science. 2000;171(1):119-30.

[18] Devrim Y, Albostan A. Enhancement of PEM fuel cell performance at higher temperatures and lower humidities by high performance membrane electrode assembly based on Nafion/zeolite membrane. International Journal of Hydrogen Energy. 2015;40(44):1532835.

[19] Cui Y, Baker AP, Xu X, Xiang Y, Wang L, Lavorgna M, et al. Enhancement of Nafion based membranes for direct methanol fuel cell applications through the inclusion of ammonium-X zeolite fillers. Journal of Power Sources. 2015;294:369-76.

[20] Kongkachuichay P, Pimprom S. Nafion/Analcime and Nafion/Faujasite composite membranes for polymer electrolyte membrane fuel cells. Chemical Engineering Research and Design. 2010;88(4):496-500.

[21] Yoonoo C, Dawson CP, Roberts EPL, Holmes SM. Nafion®/mordenite composite membranes for improved direct methanol fuel cell performance. Journal of Membrane Science. 2011;369(1-2):367-74.

[22] Breck DW. Zeolite molecular sieves: structure, chemistry, and use: Wiley; 1973. [23] Van der Bruggen B, Schaep J, Wilms D, Vandecasteele C. Influence of molecular size, polarity and charge on the retention of organic molecules by nanofiltration. Journal of Membrane Science. 1999;156(1):29-41.

[24] Gao Y, Robertson GP, Guiver MD, Jian X, Mikhailenko SD, Wang K, et al. Sulfonation of poly(phthalazinones) with fuming sulfuric acid mixtures for proton exchange membrane materials. Journal of Membrane Science. 2003;227(1-2):39-50. 
[25] Hibino T, Akimoto T, Iwahara H. Protonic conduction of mordenite-type zeolite. Solid State Ionics. 1993;67(1-2):71-6.

[26] Baglio V, Di Blasi A, Aricò AS, Antonucci V, Antonucci PL, Nannetti F, et al. Investigation of the electrochemical behaviour in DMFCs of chabazite and clinoptilolitebased composite membranes. Electrochimica Acta. 2005;50(25-26):5181-8.

[27] Zhou T, Li L, Jie C, Shen Q, Xie Q, Hao Z. Fe-mordenite/cordierite monolith for the catalytic decomposition of nitrous oxide. Ceramics International. 2009;35(8):3097-101.

[28] Alberti G, Casciola M. COMPOSITE MEMBRANES FOR MEDIUM-TEMPERATURE PEM FUEL CELLS. Annual Review of Materials Research. 2003;33(1):129-54.

[29] Li Y, Guan H-M, Chung T-S, Kulprathipanja S. Effects of novel silane modification of zeolite surface on polymer chain rigidification and partial pore blockage in polyethersulfone (PES)-zeolite A mixed matrix membranes. Journal of Membrane Science. 2006;275(1-2):1728.

[30] Duval JM, Kemperman AJB, Folkers B, Mulder MHV, Desgrandchamps G, Smolders CA. Preparation of zeolite filled glassy polymer membranes. Journal of Applied Polymer Science. 1994;54(4):409-18.

[31] Metın D, Tihminlioğlu F, Balköse D, Ülkü S. The effect of interfacial interactions on the mechanical properties of polypropylene/natural zeolite composites. Composites Part A: Applied Science and Manufacturing. 2004;35(1):23-32.

[32] Boom JP, Pünt IGM, Zwijnenberg H, de Boer R, Bargeman D, Smolders CA, et al. Transport through zeolite filled polymeric membranes. Journal of Membrane Science. 1998;138(2):237-58.

[33] Kwak S-H, Yang T-H, Kim C-S, Yoon KH. Nafion/mordenite hybrid membrane for high-temperature operation of polymer electrolyte membrane fuel cell. Solid State Ionics. 2003;160(3-4):309-15.

[34] Takahashi T, Tanimoto R, Isobe T, Matsushita S, Nakajima A. Surface modification of porous alumina filters for $\mathrm{CO} 2$ separation using silane coupling agents. Journal of Membrane Science. 2016;497:216-20.

[35] Zhao J, Milanova M, Warmoeskerken MMCG, Dutschk V. Surface modification of TiO2 nanoparticles with silane coupling agents. Colloids and Surfaces A: Physicochemical and Engineering Aspects. 2012;413:273-9.

[36] Wang C, Li Y, Shi H, Huang J. Preparation and characterization of natural zeolite supported nano $\mathrm{TiO} 2$ photocatalysts by a modified electrostatic self-assembly method. Surface and Interface Analysis. 2015;47(1):142-7.

[37] Horvat CI, Zhu X, Türp D, Vinokur RA, Demco DE, Fechete R, et al. Perfluorosulfonic acid ionomer - silica composite membranes prepared using hyperbranched polyethoxysiloxane for polymer electrolyte membrane fuel cells. International Journal of Hydrogen Energy. 2012;37(19):14454-62.

[38] Wu H, Zheng B, Zheng X, Wang J, Yuan W, Jiang Z. Surface-modified Y zeolite-filled chitosan membrane for direct methanol fuel cell. Journal of Power Sources. 2007;173(2):84252.

[39] Intaraprasit N, Kongkachuichay P. Preparation and properties of sulfonated poly(ether ether ketone)/Analcime composite membrane for a proton exchange membrane fuel cell (PEMFC). Journal of the Taiwan Institute of Chemical Engineers. 2011;42(1):190-5. [40] Moore RB, Martin CR. Chemical and morphological properties of solution-cast perfluorosulfonate ionomers. Macromolecules. 1988;21(5):1334-9.

[41] Lin Y-F, Yen C-Y, Ma C-CM, Liao S-H, Lee C-H, Hsiao Y-H, et al. High protonconducting Nafion ${ }^{\circledR} /-\mathrm{SO} 3 \mathrm{H}$ functionalized mesoporous silica composite membranes. Journal of Power Sources. 2007;171(2):388-95.

[42] Li Y, Nguyen QT, Schaetzel P, Lixon-Buquet C, Colasse L, Ratieuville V, et al. Proton exchange membranes from sulfonated polyetheretherketone and sulfonated polyethersulfone- 
cardo blends: Conductivity, water sorption and permeation properties. Electrochimica Acta. 2013;111(0):419-33.

[43] Mukoma P, Jooste BR, Vosloo HCM. A comparison of methanol permeability in Chitosan and Nafion 117 membranes at high to medium methanol concentrations. Journal of Membrane Science. 2004;243(1-2):293-9.

[44] Lin H, Zhao C, Ma W, Shao K, Li H, Zhang Y, et al. Novel hybrid polymer electrolyte membranes prepared by a silane-cross-linking technique for direct methanol fuel cells. Journal of Power Sources. 2010;195(3):762-8.

[45] Lin H, Zhao C, Jiang Y, Ma W, Na H. Novel hybrid polymer electrolyte membranes with high proton conductivity prepared by a silane-crosslinking technique for direct methanol fuel cells. Journal of Power Sources. 2011;196(4):1744-9.

[46] Kim H, Prakash S, Mustain WE, Kohl PA. Sol-gel based sulfonic acid-functionalized silica proton conductive membrane. Journal of Power Sources. 2009;193(2):562-9.

[47] Jana R, Bhunia H. Thermal stability and proton conductivity of silane based nanostructured composite membranes. Solid State Ionics. 2008;178(37-38):1872-8.

[48] Wang Y, Jiang Z, Li H, Yang D. Chitosan membranes filled by GPTMS-modified zeolite beta particles with low methanol permeability for DMFC. Chemical Engineering and Processing: Process Intensification. 2010;49(3):278-85.

[49] Li C, Sun G, Ren S, Liu J, Wang Q, Wu Z, et al. Casting Nafion-sulfonated organosilica nano-composite membranes used in direct methanol fuel cells. Journal of Membrane Science. 2006;272(1-2):50-7.

[50] Onyechi PC, Asiegbu KO, Igwegbe CA, Nwosu MC. Effect of particle size on the mechanical properties of perwinkle shell reinforced polyester composite (PRPC) International Journal of Scientific \& Engineering Research. 2015;6(3):1064-96.

[51] Zhang S, Cao XY, Ma YM, Ke YC, Zhang JK, Wang FS. The effects of particle size and content on the thermal conductivity and mechanical properties of A12O3/high density polyethylene (HDPE) composites. eXPRESS Polymer Letters. 2011;5(7):581-90.

[52] Fu S-Y, Feng X-Q, Lauke B, Mai Y-W. Effects of particle size, particle/matrix interface adhesion and particle loading on mechanical properties of particulate-polymer composites. Composites Part B: Engineering. 2008;39(6):933-61.

[53] Peighambardoust SJ, Rowshanzamir S, Amjadi M. Review of the proton exchange membranes for fuel cell applications. International Journal of Hydrogen Energy. 2010;35(17):9349-84.

[54] Wu G, Swaidan R, Cui G. Electrooxidations of ethanol, acetaldehyde and acetic acid using PtRuSn/C catalysts prepared by modified alcohol-reduction process. Journal of Power Sources. 2007;172(1):180-8.

[55] Kamarudin MZF, Kamarudin SK, Masdar MS, Daud WRW. Review: Direct ethanol fuel cells. International Journal of Hydrogen Energy. 2013;38(22):9438-53.

[56] Levenspiel O. Chemical Reaction Engineering, 3rd ed.: Wiley India Pvt. Limited; 2006.

[57] Arkles B. Hydrophobicity, Hydrophilicity and Silane Surface Modification. Paint \& Coatings Industry. Troy, Michigan: BNP Media; 2006. 


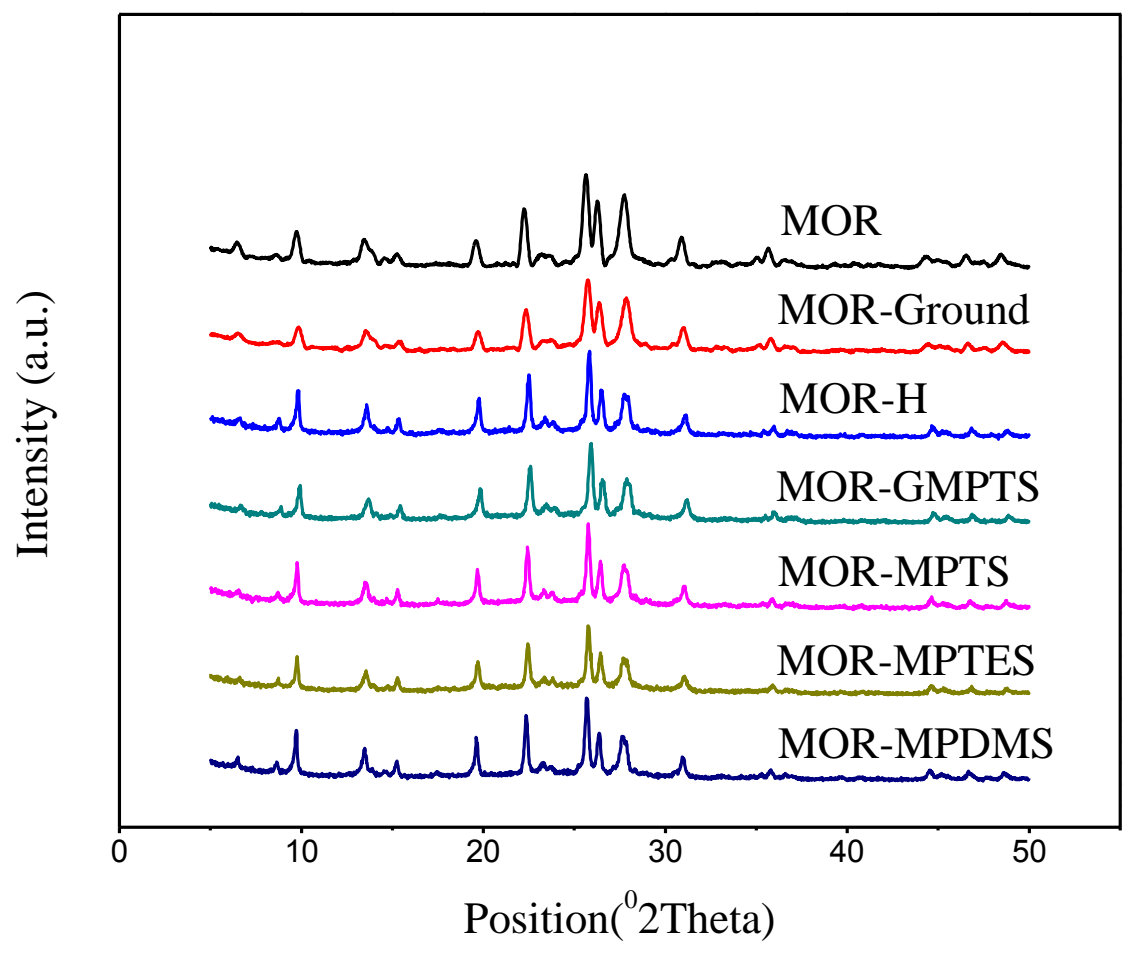

Fig. 1. XRD patterns of as-purchased MOR and MOR after the treatment steps of grinding, protonating, and functionalization. 


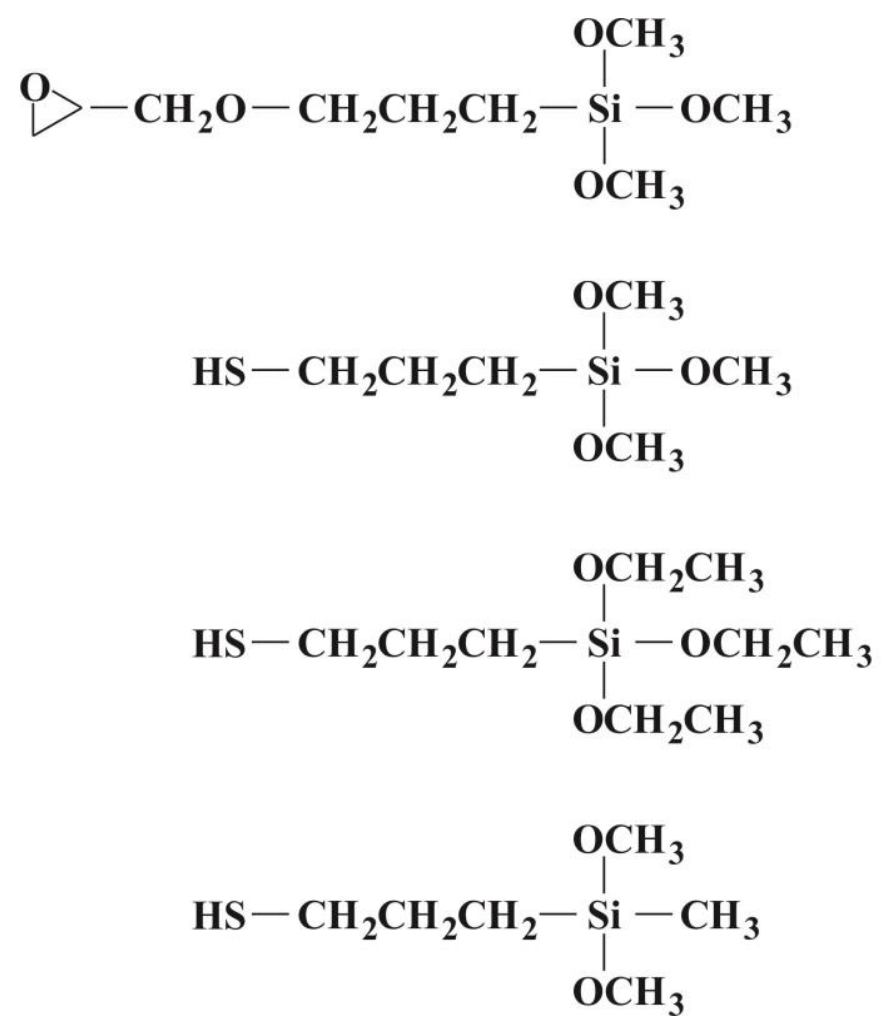

Fig. 2. Structures of silanes (a) GMPTS (b) MPTS (c) MPTES and (d) MPDMS. 

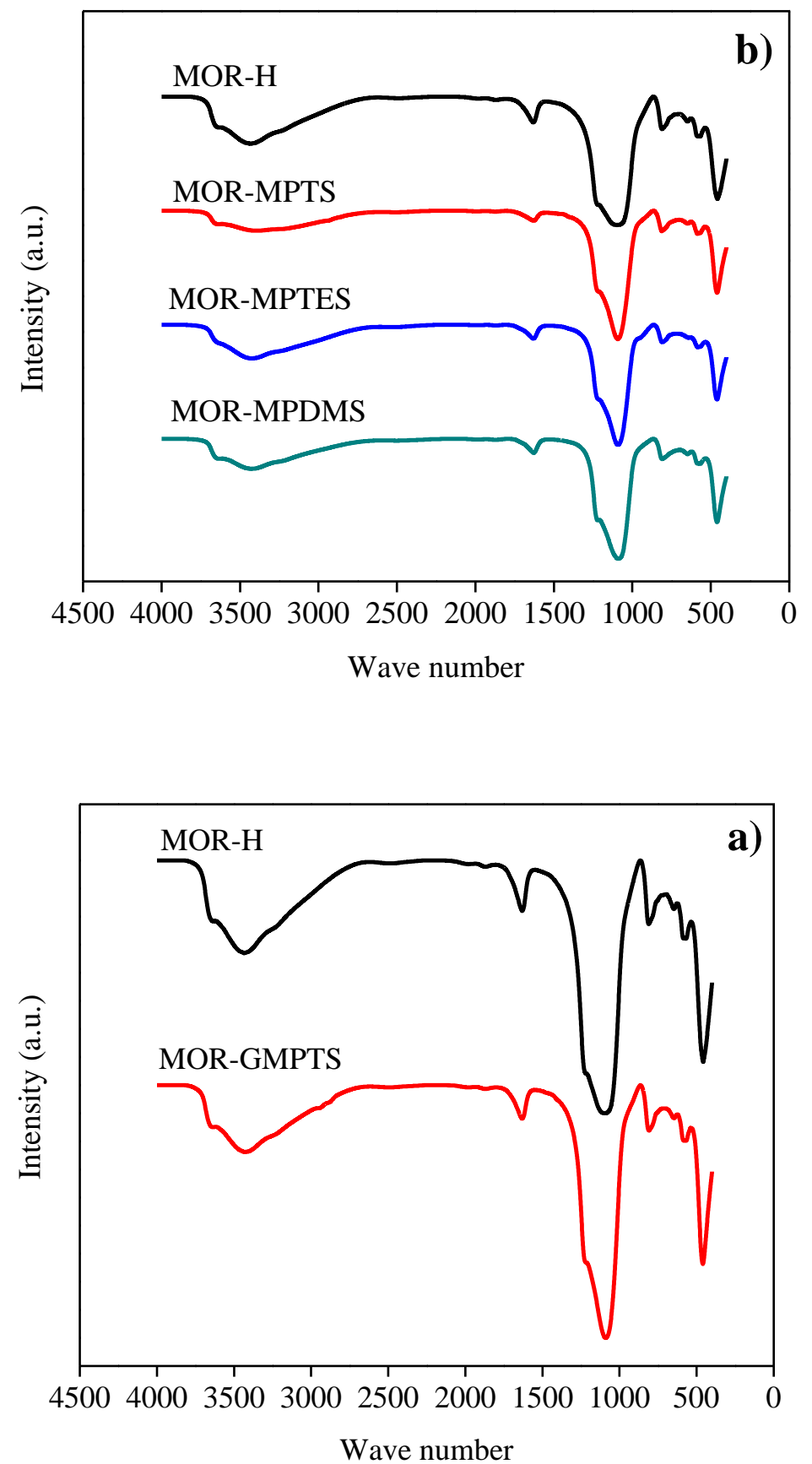

Fig. 3. FT-IR results of MOR-H compared with (a) MOR-GMPTS and (b) MOR-MPTS, MOR-MPTES and MOR-MPDMS. 


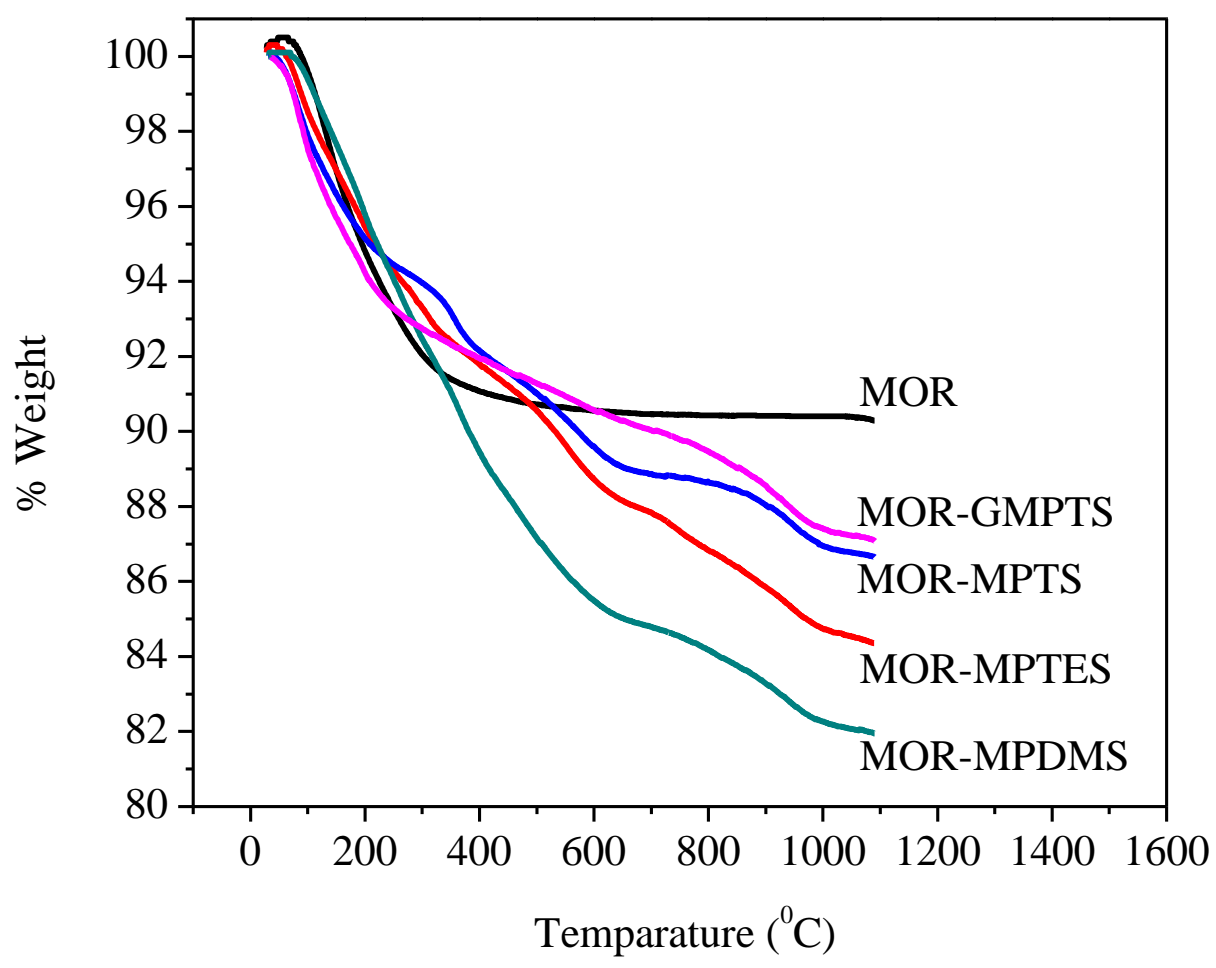

Fig. 4. The TGA results of MOR before and after treatment by different types of silanes. 

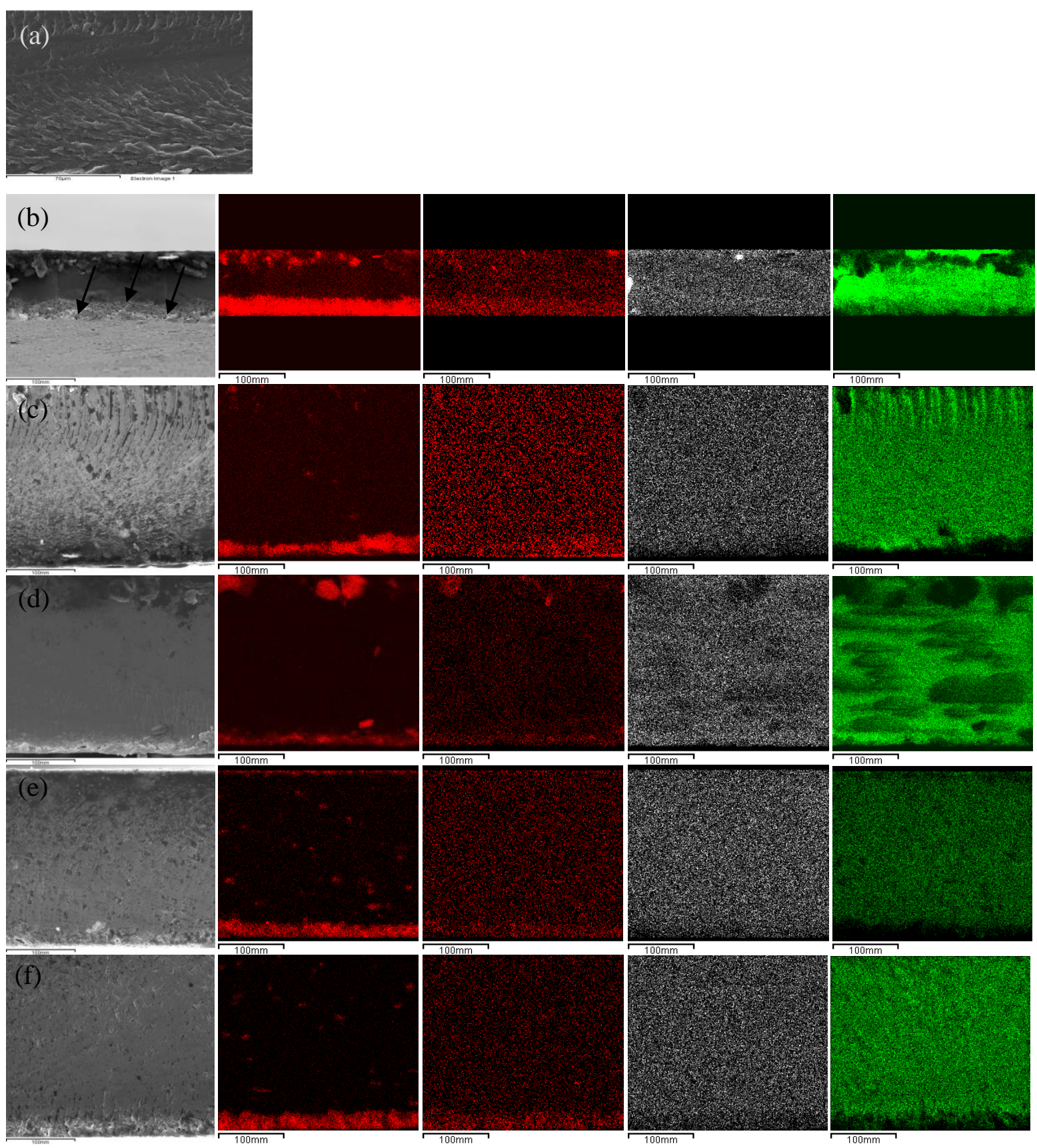

Fig. 5. SEM images (first image on the left) and EDS mapping $\left(2^{\text {nd. }}:\right.$ Si-element mapping, $3^{\text {rd }}$ : Al-element mapping, $4^{\text {th }}$ : S-element mapping, and last images: F-element mapping) of (a) recast Nafion membrane, (b) Nafion/MOR membrane, (c) Nafion/MOR-GMPTS membrane,

(d) Nafion/MOR-MPTS membrane, (e) Nafion/MOR-MPTES membrane and (f) Nafion/MOR-MPDMS membrane. 


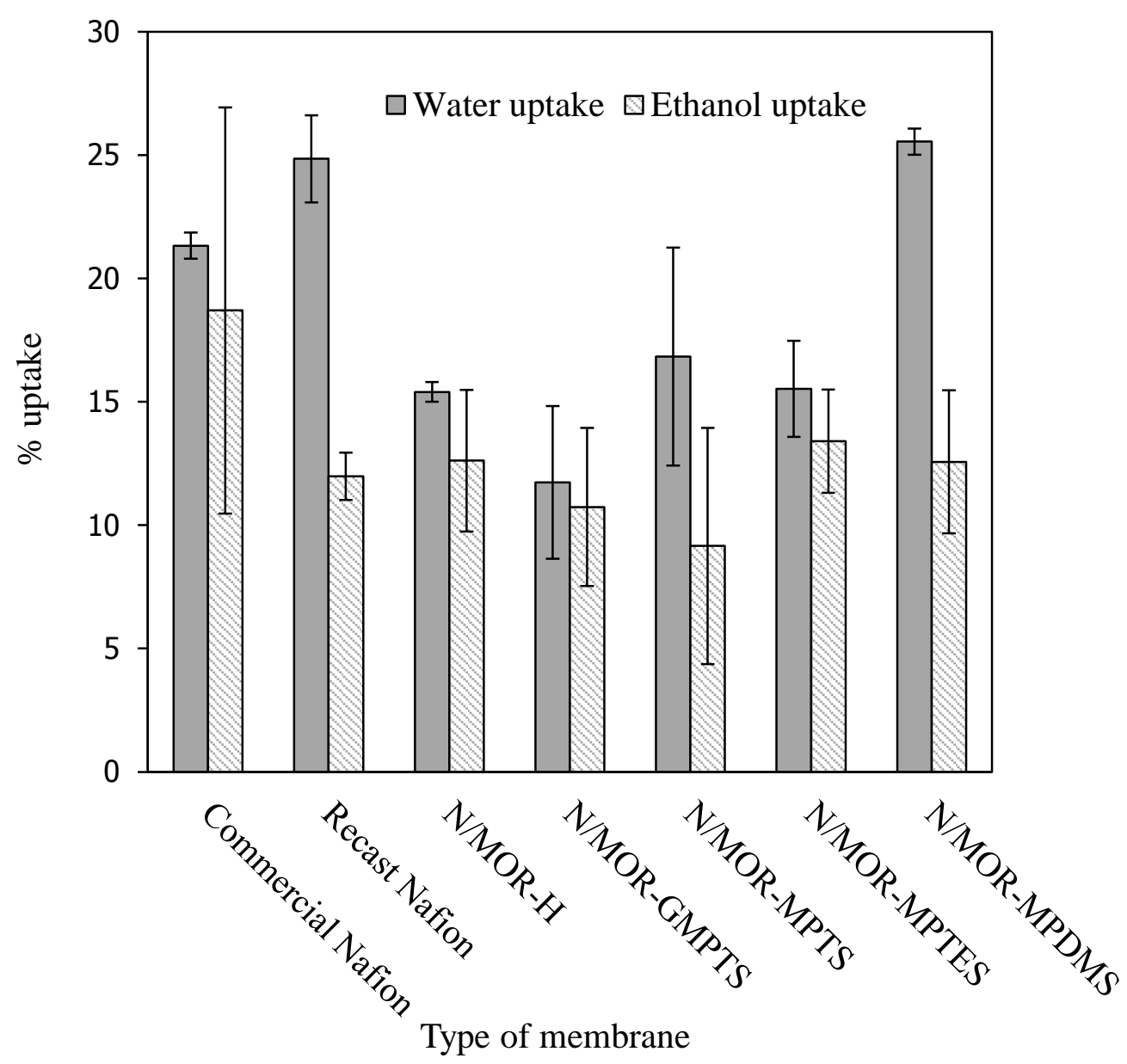

Fig. 6. Water and ethanol uptake of composite membranes. 


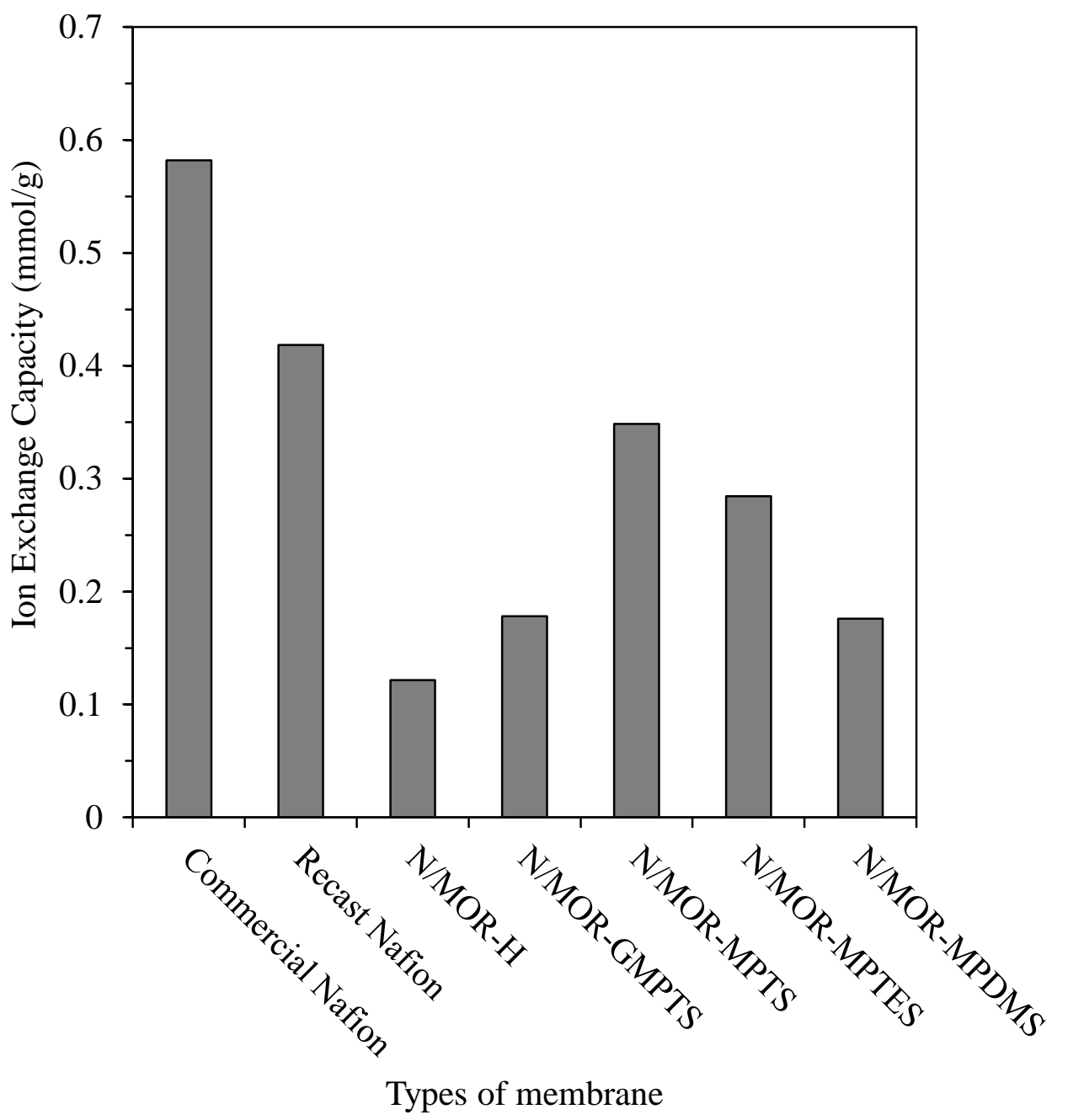

Fig. 7. Ion exchange capacity composite membranes. 


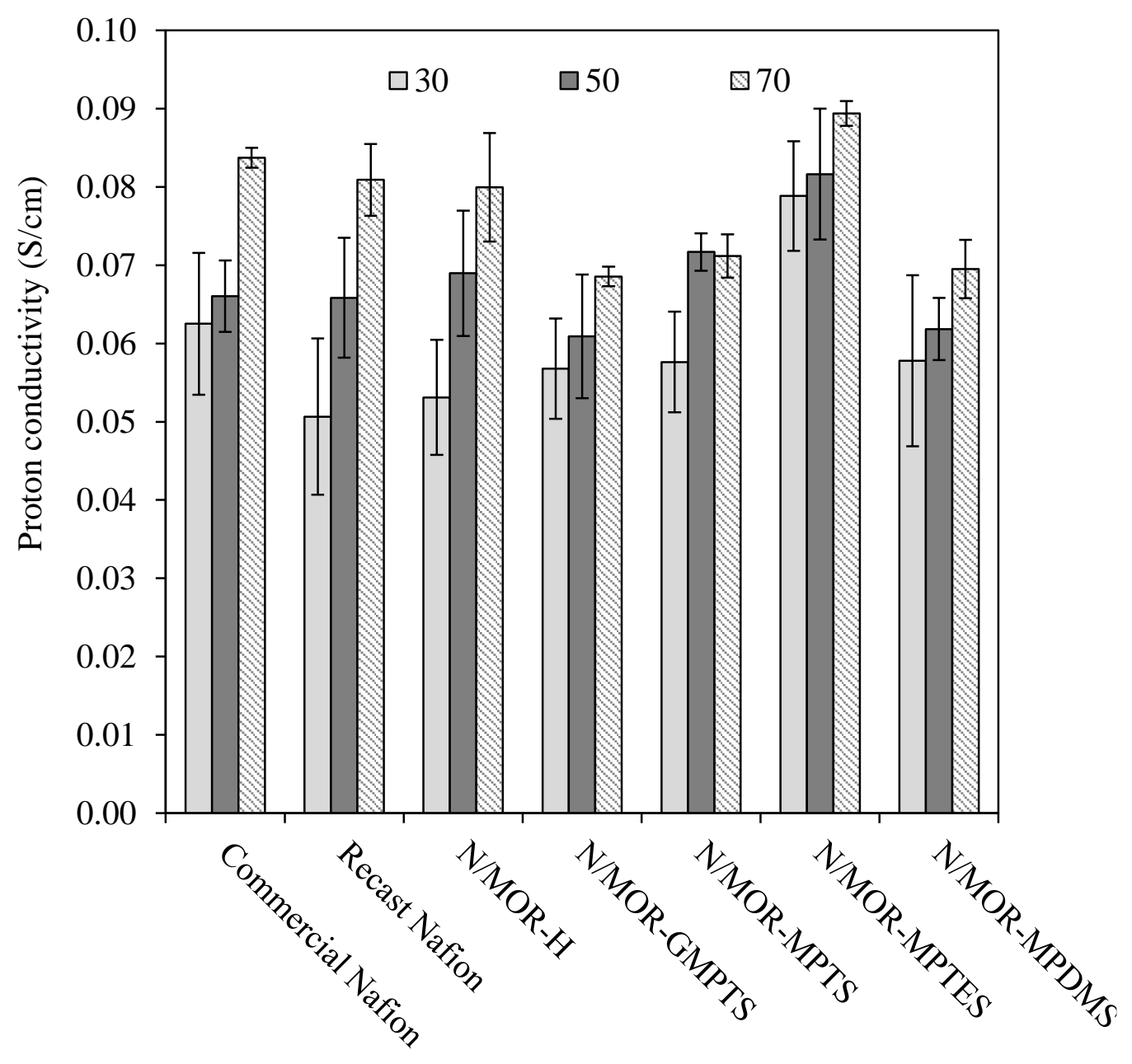

Types of membrane

Fig. 8. Proton conductivity of each membrane at $30{ }^{\circ} \mathrm{C}, 50{ }^{\circ} \mathrm{C}$ and $70{ }^{\circ} \mathrm{C}$. 


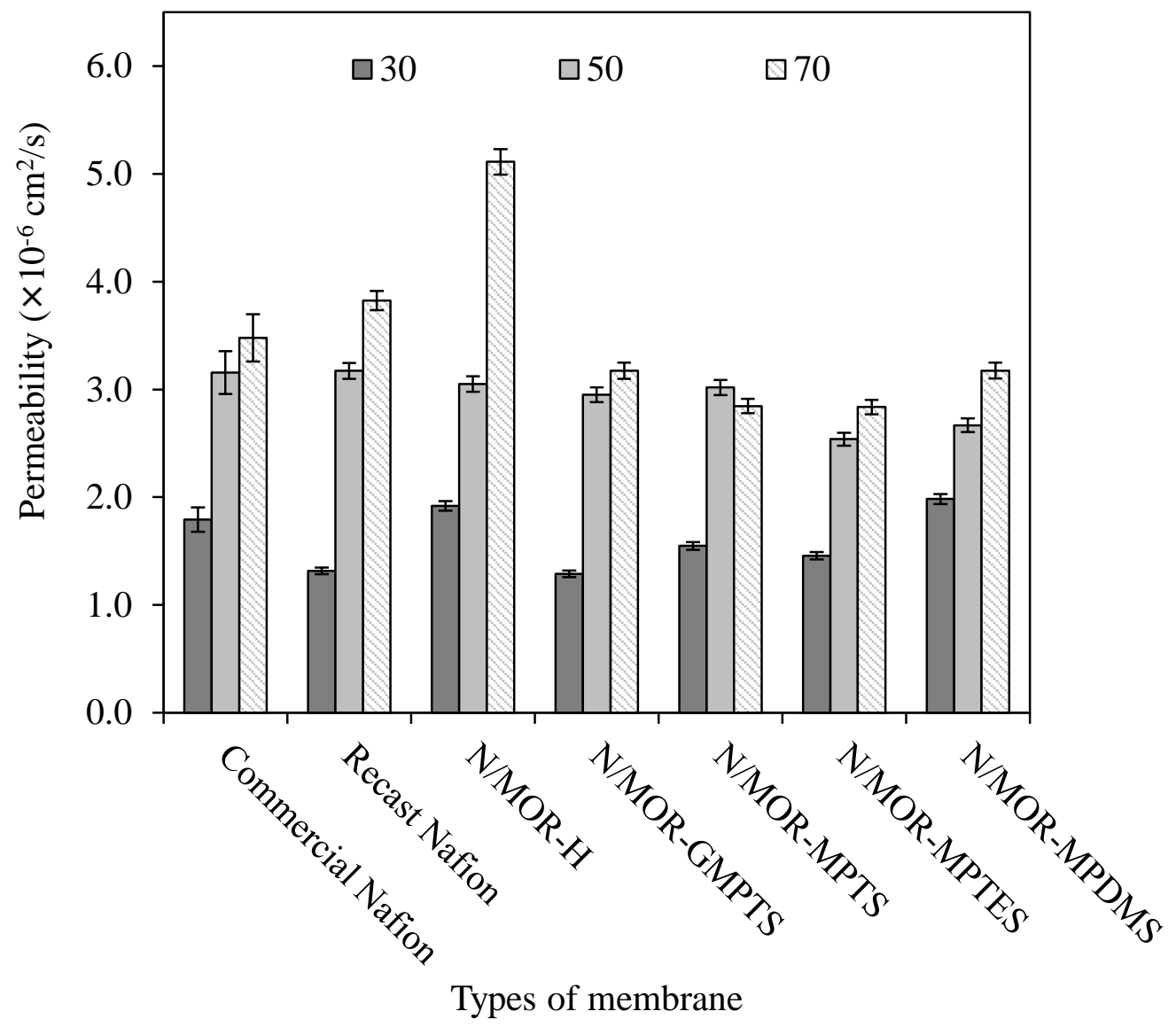

Fig. 9. Ethanol permeability of all types of membranes at $30{ }^{\circ} \mathrm{C}, 50{ }^{\circ} \mathrm{C}$ and $70{ }^{\circ} \mathrm{C}$ at $1 \mathrm{M}$ ethanol concentration. 


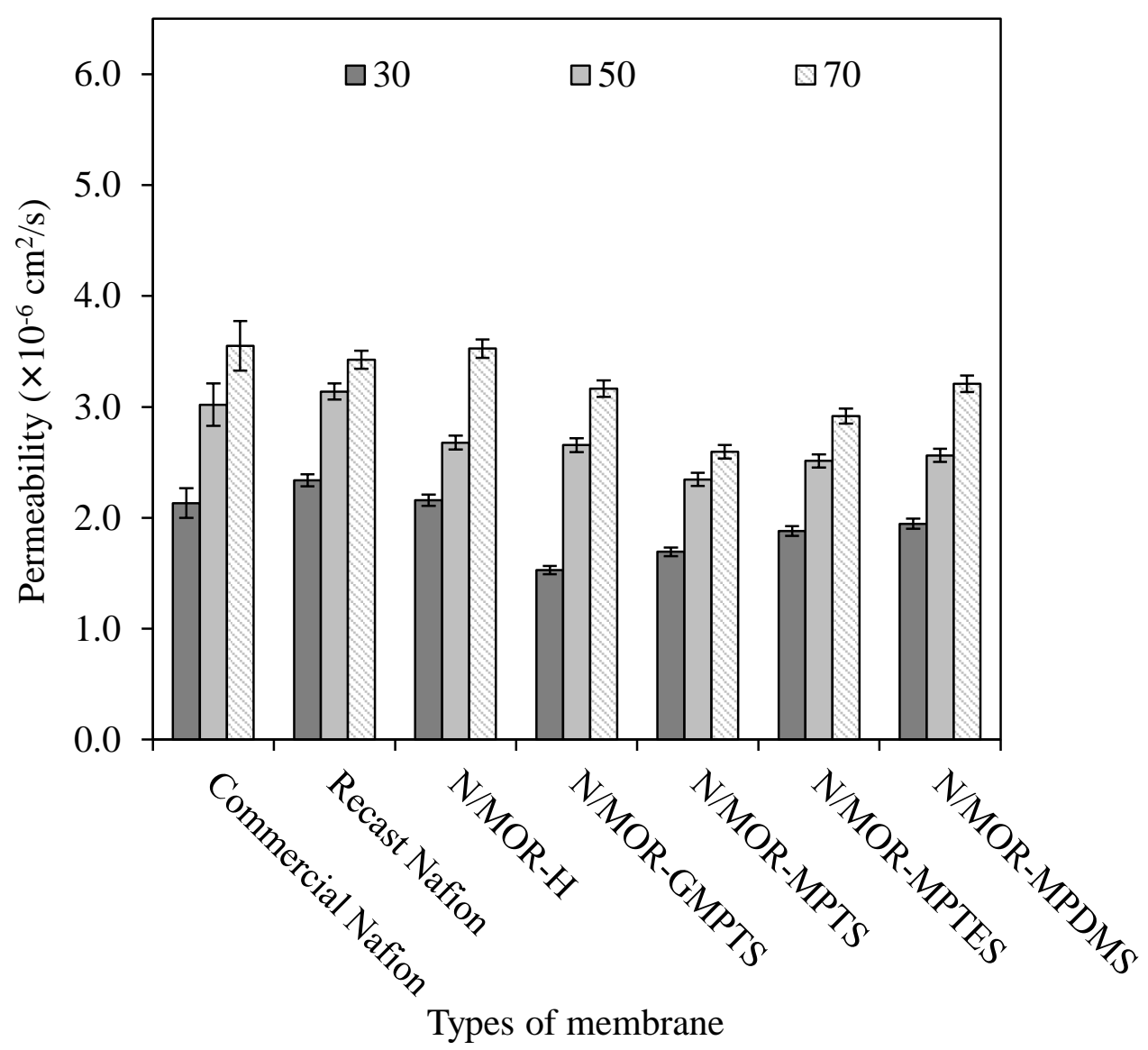

Fig. 10. Ethanol permeability of all types of membranes at $30{ }^{\circ} \mathrm{C}, 50{ }^{\circ} \mathrm{C}$ and $70{ }^{\circ} \mathrm{C}$ at $2 \mathrm{M}$ ethanol concentration. 


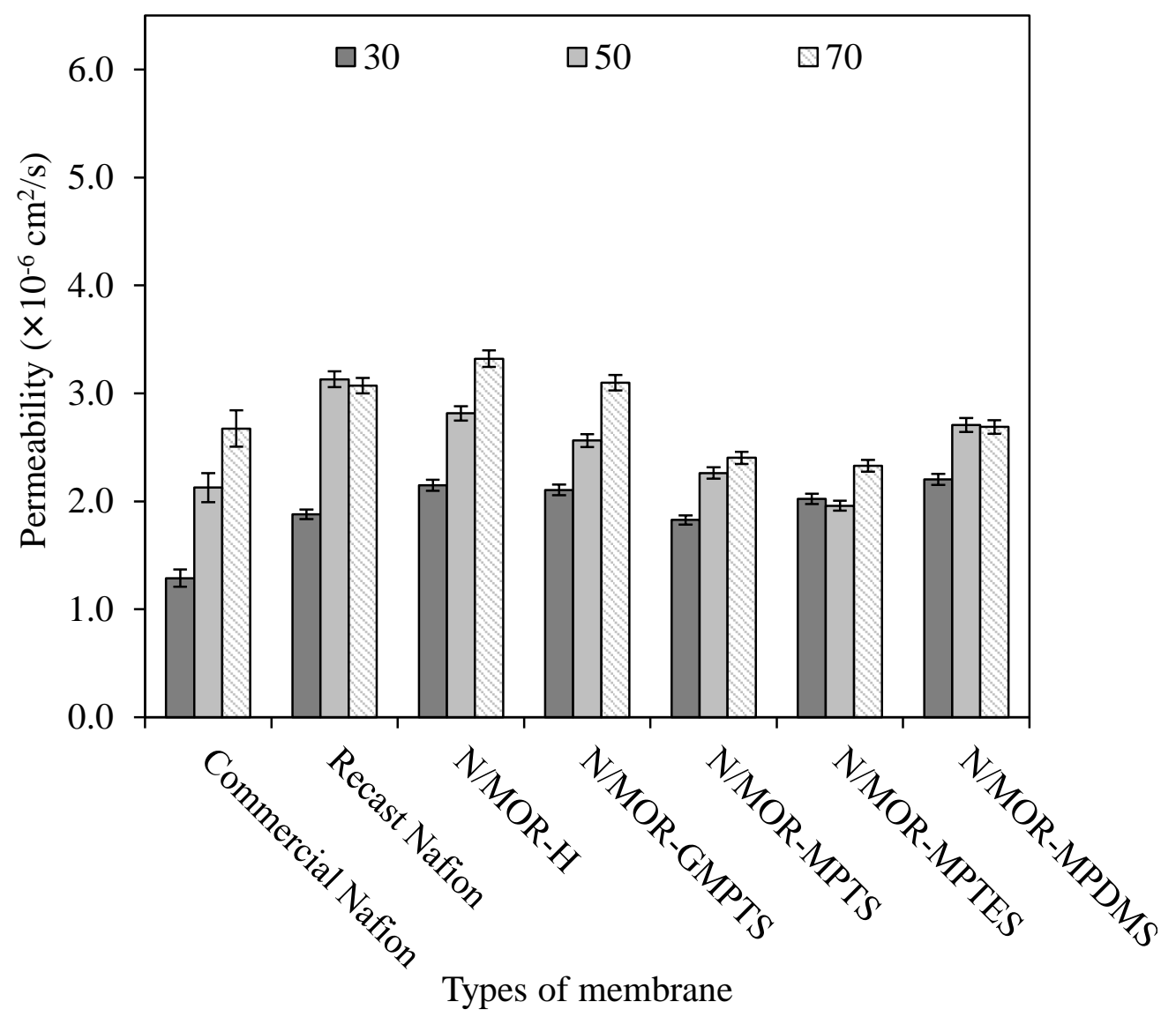

Fig. 11. Ethanol permeability of all types of membranes at $30{ }^{\circ} \mathrm{C}, 50{ }^{\circ} \mathrm{C}$ and $70{ }^{\circ} \mathrm{C}$ at $4 \mathrm{M}$ ethanol concentration. 